\title{
Internal Efforts of Improving Spirituality of Ministry Apartment of Religion, Medan City
}

\author{
Impun Siregar ${ }^{1}$, Muzakkir $^{2}$, Anwarsyah Nur ${ }^{3}$ \\ ${ }^{1}$ Ph.D Student in State Islamic University of North Sumatera (UINSU), Medan, Indonesia \\ ${ }^{2,3}$ Lecturer in State Islamic University of North Sumatera (UINSU), Medan, Indonesia \\ Impun_siregar@yahoo.co.id
}

\begin{abstract}
The aim of this research is to analyze the spirituality of the State Civil Apparatus at the Office of the Ministry of Religion in Medan, the researcher will link and relate the benchmarks of this research to the Indonesian Minister of Religion's program "Five Values of Work Culture". This program is the spirit of the Ministry of Religion so that work and work are more meaningful and have values that bind and inspire them. The research methodology use qualitative research. The study conducted by the State Civil Apparatus of the Ministry of Religion in Medan is an activity that has the aim of forming good, faithful, pious, and virtuous Muslims. The purpose of recitation is the same as the purpose of Da'wah, which is to go to the righteous and stay away from the evil.
\end{abstract}

Keywords: Spirituality of ministry; apartment of religion; Da'wah.

\section{Introduction}

The Ministry of Religion Apparatus in implementing its program must be able to realize a society that is religiously obedient, has high spirituality and is able to be an example, namely having individual and social piety. Individual and social piety is very necessary for everyone,

Normatively this situation should produce godly social realities as well. However, what has happened in the reality of Indonesia to this day is a condition that is really very sad. The practice of life and community life shows conditions that are contrary to religious norms.

Individual piety is related to special worship (ritual worship), namely worship such as prayer, fasting, almsgiving, pilgrimage, remembrance and others. In this sense, a Muslim has a better relationship with God and for his own sake. These self-interests such as calmness, hope to enter heaven (perhaps), the expectation of prayer being granted, the hope for his own success. Meanwhile, social piety refers to the behavior of individuals who are very concerned with social values. That is, a person who has social piety, he will care about social problems such as actively caring for the poor, behaving politely, not corruption, being helpful, very attentive to the problems faced by society, able to empathize and so forth.

A pious person is a person who is devout in his particular worship (ritual) with well and then fulfills his promises in that particular worship in daily life, is active in overcoming the problems of society, active in alleviating poverty, active in realizing a just political face, active in upholding justice. In short, a pious person who has a noble character both in attitude, words and behavior.

Spiritual experiences are experiences of union with the universe that cannot be obtained in the ordinary conscious state. Positive emotions are strongly associated with feelings of gratitude, the ability to manage thoughts and feelings in intrapersonal relationships so that a person can have the value of life that underlies the ability to behave appropriately. Rituals refer to structured, systematic and repetitive actions.

Reading Al-Quran there are really many verses of the Koran and Hadist that explain about spirituality that seeks to draw closer to Allah SWT, among others: QS. Al Imran / 3: 191. 


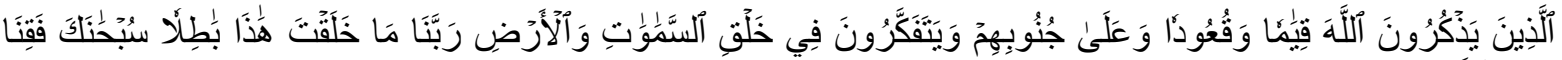

عَذَابَ ألنَّار 191

Meaning: (Ie) Those who remember Allah while standing or sitting or in a state of lying down and they think about the creation of the heavens and the earth '(while saying):" $O$ our Lord, Thou hast not created this in vain, Blessed You, then protect us from the torments of hell.

QS. Al Hadid/57:3.

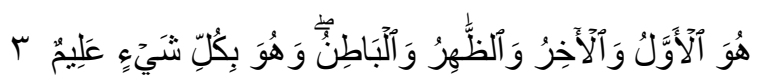

Meaning: He is the beginning and the end, the born and the inner. And He knows everything.

The State Civil Apparatus at the Ministry of Religion in Medan in implementing its program must be able to realize a religiously obedient society, have high spirituality and be able to set an example, namely having individual and social piety. Individual and social piety is very necessary for everyone.

In analyzing the spirituality of the State Civil Apparatus at the Office of the Ministry of Religion in Medan, the researcher will link and relate the benchmarks of this research to the Indonesian Minister of Religion's program "Five Values of Work Culture". This program is the spirit of the Ministry of Religion so that work and work are more meaningful and have values that bind and inspire them.

The fundamental purpose of work culture is to develop complete human resources so that everyone is aware that they are in a relationship of the nature of the role of customers, suppliers in communicating with others effectively and efficiently and happily. Work culture seeks to transform traditional communication into modern management behavior, so that trust and enthusiasm for cooperation and discipline are embedded. By getting used to quality work, such as trying to do certain ways of working, so the results are in accordance with the standards or qualifications set by the organization.

\section{Review of Literature}

\subsection{Spirituality}

According to language, 'spirituality' comes from the word 'spirit' which means 'soul'. The term "spiritual" can be defined as general human experience of an understanding of meaning, purpose and morality. According to some Sufism experts the 'soul' is the 'spirit' after being united with the body of the union of the spirit with the body giving birth to the influence created by the body of the spirit. Because from these influences arose the needs of the body built by the spirit. Therefore, it can be said that the soul is the subject of "spiritual" activities. The union of soul and spirit is to achieve the need for God.

Defining spirituality itself can be done with two approaches: theistic and non-theistic. The definition of spirituality which is often associated with religiosity uses theistic approach. Whereas the non-theistic approach is based on secular, humanistic, and existential elements. In general, spirituality is often associated with connectedness: connectedness with oneself, others, and transcendent power. Spirituality consists of three dimensions, namely the dimension of connectedness with oneself, the dimension of connectedness with others or nature, and the dimension of connectedness with transcendent sources. Relationship with 
oneself is shown by the authentic aspects, inner peace, awareness, self-understanding, and experience of the meaning of life.

Relationship with other people or nature associated with feelings of sympathy for someone who is misfortune, caring, gratitude, and emotion for something. Being connected with transcendent power is associated with connectedness with God or something that is above human understanding such as the world, the reality of life, and greater strength.

\subsection{General description of Medan City}

In ancient times the city of Medan was known as the Deli Land and the condition of the swampy land was approximately $4000 \mathrm{Ha}$. Several rivers cross the city of Medan and all of them empties into the Straits of Malacca. The rivers are Sei Deli, Sei Babura, Sei Sikambing, SeiDenai, Sei Putih, Sei Badra, Sei Belawan and SeiSulang Saling / Sei Kera.

In the beginning, the one who opened the Medan village was Guru Patimpus, which was located in Tanah Deli, so since the colonial era people always linked Medan with Deli (Medan-Deli). After the independence era the term Medan Deli gradually disappeared so that it eventually became less popular. In 1886, Medan officially gained the status of a city, and the following year became the capital of the East Sumatra Residency as well as the capital of the Deli Sultanate. In 1909, Medan became an important city outside Java, especially after the colonial government opened a large plantation company. The first city council consisted of 12 European members, two natives, and a Chinese.

Kesawan area of the 1920s. At the end of the 19th century and the beginning of the 20 th century there were two waves of large migration to Medan. The first wave was in the form of Chinese and Javanese arrivals as coolies on plantation contracts. But after 1880 the plantation companies stopped bringing in Chinese people, because most of them ran away from the garden and often rioted. The company then brought in Javanese people as plantation laborers. The former Chinese fugitives of plantations were then encouraged to develop the trade sector. The second wave is the arrival of Minangkabau, Mandailing and Aceh people. They did not come to Medan to work as plantation plots, but to trade, become teachers and scholars.

Since 1950, Medan has expanded its area several times, from 1,853 ha to 26,510 ha in 1974. Thus, within 25 years after the transfer of sovereignty, the city of Medan has expanded by nearly eighteen fold. The original location of Kampung Medan is a place where the Deli River meets the Babura River.

There are various confusions from various sources of literature regarding the origin of the word "Medan" itself.

a. From the records of Portuguese writers who came from the early 16th century, it was mentioned that Medan originated from the name "Medan",

b. Some people who stated that the word "Medan" was mentioned because this city was a meeting place or area for various tribes so it was called a meeting ground.

c. Arabic says when the Arab merchants who happened to see the terrain now they say Median which means flat or flat, and indeed in fact the terrain has a flat land contour from belawan beach to the stone shower area. and when viewed from a height the terrain looks like a flat stretch of land.

d. Karo Batak language Medan "Medan means healthy". However, it helps us restore the understanding of the term Medan itself to its proper place. If we look from historical sources that the city of Medan was first inhabited by Batak tribes, in this case KaroBatak, 
of course the word "Medan" must come from Karo Batak language. In one of KaroIndonesian Batak Dictionaries written by Darwin Prinst SH in 2002, that the word "Medan" means "to be healthy" or "better". This is indeed based on the fact that Guru Patimpus was right there was a physician who in this case had expertise in traditional BatakKaro medicine in his time.

\subsection{Ministry of Religion Office}

The description of the organization of the Department of Religion based on the Decree of the Minister of Religion Number 53 of 1971 (Concerning the Establishment of the Representatives of the Provincial Ministry of Religion and the Office of the Ministry of Religious Affairs and the Inspectorate of Representatives), the composition of the position of the Ministry of Religion are as follows: 1. Representative of the Provincial Department of Religion. 2. Representatives of the District Religion Department. 3. District Religious Affairs Office. 4. Supervision Affairs are representative Inspectorates.

The Ministry of Religion was founded in 1946, and in the course of history the Organization and Work Structure of the Ministry of Religion has been amended several times, and in accordance with Decree of the Minister of Religion No. 373 of 2002 that the Organizational Structure and Work Arrangement of the Regional Office of the Ministry of Religion of North Sumatra Province is included in Typology I.B.

At the time of the founding of the Department of Religion in 1946, Sumatra was still a Province with the Governor at that time Mr. TengkuMoch. Hasan. In line with that, the Governor of Sumatra appointed H. MuchtarYahya as the head of the "Sumatran Religious Office" whose position was under the Governor. After the Sumatra region was divided into 3 (three) Provinces, namely North Sumatra, Central Sumatra and Seiatan Sumatra Provinces, H. MukhtarYahya was appointed as the coordinator of the Religious Offices based in Bukit Tinggi. On behalf of the President of Sumatra Governor M. TengkuMoch. Hasan appointed the Heads of the Religious Departments whose main task was to draw out the government, especially religion in their respective regions, namely Teuku Moch. Daud Beureuh in the area of North Sumatra Province, Nazaruddin Thoha in Central Sumatra and K. Azhari in South Sumatra Province.

In its history after the North Sumatra Province Religious Affairs office there was a relationship with the Ministry of Religion domiciled in Yogyakarta, H. Muchtar Yahya was moved to the center to occupy a new position as Head of Religious Affairs for the Sumatra Region. North Sumatra Province which is a combination of the Aceh region, East Sumatra and Tapanuli in 1953 North Sumatra Religious Bureau at the Central Indonesian National Committee (KNIP) session and thanks to Masyumi struggle by acclamation the proposal was accepted by KNIP members, finally the Religious Council of the East Sumatra Residency was established. which was originally at the level of Mandailing in South Tapanuli Mandailing.

Before the existence of Religious Council in Tapanuli area, matters relating to religion were handled by KUA along with Kadhi, they carried out various tasks relating to religious matters such as marriage, divorce, mosque management, social worship and so on. With the birth of the Religious Council in East Sumatra and the end of the colonial period the community urged that a department be formed to deal with religious and religious issues.

In line with that, in 1946 Masyumi Conference was held in Mandailing South Tapanuli. One of the agreements was to decide to urge the government (residency) to form a "Religious 
Service" that would manage religious issues starting at the level of residency, education and sub-districts which had been implementing is called asKadhi, and in that the agreement is unanimously agreed upon, forming a Religious Service they give the name "Religious Council". Meanwhile the conference members did not yet know the news about the establishment of the Ministry of Religion at the center. The proposal by Resident Tapanuli received a quite positive response and then became an important agenda and the main discussion of KNIP as an authorized institution at that time and finally the push for the formation of the Religious Council was unanimously approved in the KNIP session.

Seeing the above conditions, Medan City did not want to be careless in taking advantage of this opportunity, so in 1946 the Medan City Department of Religious Office was established, in the midst of the hustle and bustle of the movement of the $30 \mathrm{~S} / \mathrm{PKI}$ Movement at that time. A North Sumatra KAPPI figure named AR. TarubDaulay took over a second-floor house on Jalan Bintang which was previously owned by a Chinese doctor who had escaped the hustle and bustle of the G30 S / PKJ imagery because of his involvement with the forbidden party, he tried to escape.

\section{Discussion}

To increase faith and devotion and togetherness, as well as to improveamaliyah the Ministry of Religion of Medan City program personal lectures which are routine activities every day. Like this year the activity which is a daily program, is carried out after the midday prayer on a working day outside Friday, at the Medan Ministry of Religion Mosque.

The study conducted by the State Civil Apparatus of the Ministry of Religion in Medan is an activity that has the aim of forming good, faithful, pious, and virtuous Muslims. The purpose of recitation is the same as the purpose of da'wah, which is to go to the righteous and stay away from the evil.

The study activity was held in the hope of getting merit and blessing from Allah SWT, besides that the afternoon break was filled with useful activities, said the Head of the Ministry of Religion of Medan City, H. ImpunSiregar when he was met by the publicist after the lecture, Monday (9/9). "This is the right time or moment to increase our devotion to Allah, so from now on let us draw closer to Allah, the more active in filling worship," said Siregar.

The lecture is full of blessings of mercy and forgiveness, it is only fitting that we as Muslims do not need to procrastinate anymore to increase our piety and devotion. Increasing to do good practices to achieve such great rewards provided by God, through this lecture one of them. "This activity is very good, besides to strengthen friendship and to deepen ukhuwa hislamiyah while sharing religious knowledge to increase knowledge for all ASN Office of the Ministry of Religion of Medan," said Impun Siregar.

The head office of Religious Ministry expects that lecturers are scheduled from Islamic religious instructors to increase their competence. Besides that, during Ramadhan the Qur'an is held for ASN who are Muslim. Furthermore Kasi Bimas Islam added, for the schedule of lecturers at the Ministry of Religion of the Islamic Religious Instructor (PAI) from the CPNS force to know yesterday as well as the Office of the Ministry of Religion. In addition, the PAI PNS of the Ministry of Religion in Medan also filled in the study.

Exemplary deficits, this is what often happens in the politics of our leadership. Exemplary is often absent in the leader so that almost a five-year democratic rite only 
produces the rulers, not statesmen. Only gives birth to a mentality of fear, not leaders who are ready to serve the community.

Commitment from the Chairman about providing role models and a strong will to build a strong culture in the organization he leads. Professional training programs and priorities are in career coaching. Employee Recruitment and Promotion Each employee has a set of values of honesty, integrity and a personal code of ethics. When an organization or entity is successful in preventing fraud, it is certain that the organization already has effective policies that can minimize the possibility of recruiting or promoting employees who have a low level of honesty, especially for positions that require a level of trust.

Ongoing Training New employees should be given training on organizational or entity values and implementation standards at the time of recruitment. Creating Effective Communication Channels. Information regarding the implementation and accountability of work whether or not it has been complied with the code of ethics of each employee. Each employee must be able to inform about the implementation of the code of conduct starting from the holder of the highest position to the lowest.

The auditor's internal report must be followed up by the leadership in accordance with the agreed code of ethics. Employees must be given the opportunity to report misconduct by the employee. Views of the consequences of fraud must be clearly disseminated to all employees.

One of the most important things and should not be missed is work motivation for worship. Work is in order for you to seek halal sustenance and provide for your children and family. This is worship. For this reason it should not be done arbitrarily or arbitrarily. Remember, worship is for God, it feels strange if we do it carelessly.

Everyone yearns for the best, the right job and the results that reach the target. But sometimes the name is indeed not consistent spirit, sometimes up sometimes down, sometimes excited sometimes sluggish. How else, the name of life must have ups and downs, as well as with the passion for work.

Maybe we often think, how we will achieve something that is desired while working just like this is the way, lived with the falsehood. Desire does exist but it is very difficult to get started. It would be nice if we look in the mirror to ourselves, imitating others also does not hurt.

\section{References}

Agustian, A., G. (2001). Rahasia Sukses Membangun ESQ Power, Sebuah Inner Journey Melalui Ihsan, Jakarta: Penerbit Arga.

Amnuhai, S. (2003). Manajemen Sumber daya Manusia, Jakarta: Bumi Aksara.

Arwani, A. (2013). "Peran Spiritualitas dan Religiusitas bagi Guru dalam Lembaga Pendidikan," Forum Tarbiyah.

Asy'arie, M. (1999). Filsafat Islam tentang Kebudayaan Yogyakarta: LESFI.

Audah, A., Q. (1985). 'Al Islam baina Jahli Abna'ihi wa 'Ajzi 'Ulama'ihi .tt: al Itihad al Islami al 'Alami lil Munadhomat ath thulabiyah.

Badan Litbang and Diklat Kementrian Agama RI, Buku pengembangan Budaya Kerja DepartemenAgama Jakarta: 2009

Bagus, L. (1996). Kamus Filsafat Jakarta: Gramedia. 
Bremen, Jan. (1996). Menjinakkan Sang Kuli : Politik Kolonial, Tuan Kebun, danKuli di Sumatera Timur,Translation. Toer, Koesalah Soebagyo, Jakarta : Pustaka Utama Grafit.

Bryan S. Turner. (2010). The New Black well Companion to The Sociology of Religion Blackwell Publishing Ltd.

Buiskool, Dirk A. (2007). Orang-orang yang membawa kontribusi yang positif terhadap Sumatera Timur, masa 1860-1942. Dipresentasikan pada Seminar: "Para Tokoh, Pejuang dan Pahlawan Sumatera Utara" Diselenggarakan oleh Pusat Studi Sejarah dan Imu- ilmu Sosial (PUSSIS) Negeri Universitas Medan, Medan.

Canda, E.R., \& Furman, L.D. (2010). Spiritual diversity in social work practice: The heart of helping. (New York: Oxford University Press.

Cash, K. C. and G. R. Gray. (2000). A Framework for Accommodating Religion and Spirituality in the Workplace. Academy of Management Executive. Vol. No. 3.

Casram. (2016). "Membangun Sikap Toleransi Beragama dalam Masyarakat Plural," Wawasan,

Ciarrocchi, J.W. Dy-Liacco, G.S., \& Deneke, E. (2008). God or rituals?Relational faith, spiritual discontent, and religious practices as predictors of hope and optimism. The Journal of Positive Psychology.

Danim, Sudarwan, (2000). Menjadi Peneliti Kualitatif. Bandung: Pustaka Setia.

Diener, E., Tay, L., \& Myers, D.G. The religion paradox: If religion makes people happy, why are so many dropping out? Journal of Personality and Social Psychology, vol: 101 (6)-2011.

Dinas Kebudayaan and Pariwisata Kota Medan, Jelajah Medan Heritage, VisitMedanYears 2013.

Fahruddin Muhammad, (2016). Pengaruh Nilai-nilai Agama dan Budaya Kerja dalam pencegahan tindak koruftif di lingkungan Kementrian Agama, Jakarta: Badan Litbang dan Diklat Kemenag RI,

Fahrurrozi. (2015). "Ekspresi Keberagamaan Masyarakat Islam Indonesia: Mozaik Multikulturalisme Indonesia," Toleransi, Vol. 7, No. 1.

Fauzan, (2005) "Pengaruh Religiusitas terhadap Prestasi Kerja Pegawai Negeri Sipil (PNS) Alumni danBukan Alumni Pesantren di Kantor Depag Kota Malang," Sinergi, (EdisiKhusus on Human Resources.

Fuad, Nashori dan Rachmy Diana Mucharam (2002) Mengembangkan Kreativitas dalam Perspektif Psikologi Islam. Yogyakarta: Menara Kudus.

Griffin, David Ray (2005) Visi-visi Postmodern: Spiritualitas dan Masyarakat, Yogyakarta: Kanisius.

Hans H. Penneret. Et al. (2006). Encyclopedia of World Religions. Encyclopedia Britannica

Harahap, Syahrin. (2015).Islam dan Modernitas, Dari teori Modernisasi hingga penegakan kesalehan modern, Jakarta: Prenadamedia:Jakarta.

Harmain. (2001)Topografi Kabupaten/Kota Sumatera Utara; Bappeda-SU.

Hawa, Sa'id. (1995) Jalan Ruhaniah, translation: Drs. Khairul Rafie' M. dan Ibnu Tha Ali, Bandung: Mizan.

Hawari, Dadang (2004) Al-Qur'an: Ilmu Kedokteran Jiwa Dan Kesehatan Jiwa,Yogyakarta: Dana Bhakti Prima Yasa.

Husny (1986) Butir-bitir Adat Budaya Melayu Pesisir Sumatera Timur, Jakarta: Depdikbud. Ibrahim, MuhammadZaki. (2006).TasawufHitamPutihSolo:TigaSerangkai. 
Ismail, Husein. (1984). Antara Dunia Melayu dengan Dunia Indonesia. Kuala Lumpur: Universiti Kebangsaan Malaysia.

Jonathan Z. Smith (ed) (1995), The Harper Collins Dictionary of Religion, (New York: Harper Collins Publisher Inc.

Kartini Kartono (1990), Pengantar Metodologi Research Sosial, Bandung: PN Alumni.

Luckman Sinar Basarshah II (2008). Orang India Di Sumatera Utara. Medan: FORKALA.

Luckman Sinar Basarshah II (2001). Sejarah Medan Tempoe Doloe. Medan:Perwira.

Luckman Sinar Basarshah II, Tanah Ulayat Orang Melayu di Sumatera Utara; di antara Pengakuan dan Pemasungan. Makalah seminar Internasional pemikiran Tengku Lukman Sinar tentang kemelayuan dan keIndonesiaan, USU 23 ${ }^{\text {rd }}$ of February 2011

Luckman Sinar Basarshah II, Tuanku Bangun dan Runtuhnya Kerajaan Melayu di Sumatera Timur, t.t.p.:t.p., t.t.

Maksum, Ali. (2003).Tasawuf Sebagai Pembebasan Manusia Modern: Telaah Signifikasi Konsep Tradisionalisme Islam, Surabaya: PS4M.

Mas'ud, Abdurrahman. (2017). Peningkatan Integritas Birokrasi, arah baru disiplin Pegawai (Jakarta :Balai Litbang dan Diklat Puslitbang Bimas Agama dan Layanan Keagamaan Kementrian Agama RI.

Meezenbroek, Eltica de Jager., et al. (2012). Measuring Spirituality as a Universal Human Experience: Development of the Spiritual Attitude and Involvement List (SAIL). Journal of Psychosocial Oncology, vol: 30-2.

Meleong, Lexy J,. (2004). Metodologi Penelitian Kualitatif. Jakarta: Remaja Rosda Karya.

Menpan. (2002). Keputusan Menpan no 25/Kep/M.Pan/4/2002 tentang Pedoman Pengembangan Budaya Kerja Aparatur Negara, Jakarta: Kantor Menpan.

Mitroff, I. I dan E. A. Denton. A (1999). Study of Spirituality in the Workplace. Sloan Management Review. Summer.

Moekijat. (2006).Asas-Asas Perilaku Kerja, Bandung : CV. MandarMaju.

Mulkhan, Munir. (2005).Kesalehan Mulikultural, (Jakarta: PusatStudi Agama danPeradaban (PSAP) Muhammadiyah.

Muzakkir. (2012) JalanMudahMenujuTuhan, Bandung: Perdana Publishing.

Nasr, Sayyed Hossein.(2002). "Pendahuluan" dalamSeyyedHossein Nasr (ed.), Ensiklopedi Tematis Spirilualitas Islam, Pondasi, translation. RohmaniAstuti, Bandung: Mizan.

Nasution, Harun. (2009). Islam Ditinjau dari Berbagai Aspeknya. Jakarta: UI Press.

Nasution, S. (2003). Metode Penelitian Ilmiah: Naturalistik Kualitatif. Bandung: Tarsito.

Nawawi, Hadari (2003). Manajemen Sumber Daya Manusia, Cetakan kelima, Yogyakarta : Gajah Mada University Press.

Ndraha, Taliziduhu. (2003). Teori Budaya Kerja, Cet II, Jakarta: PT. Rineka Cipta. Ngainun Naim, “Kebangkitan Spiritualitas Masyarakat Modern,” Kalam.December 2013.

Osborn and Plastrik. (2002).Manajemen Sumber Daya Mausia, Yogyakarta : BPFE.

Oxford Advanced Learners Dictionary, Oxford, University Press. 1995.

Pargament, K.I. The Psychology of religion and spirituality? Yes and no. Psychology of Religion News Letter, Vol. 22 (3)-1997.

Poerwad arminta. (1986). KamusUmum Bahasa Indonesia, Pusat Pembinaan dan Pengembangan Bahasa Departemen Pendidikan dan Kebudayaan, Jakarta: Balai Pustaka.

Prasetya, Triguno.(2001). Manajemen SumberDaya Manusia, Jakarta :Bumi Aksara. 
Reid, Antony. (2011) Menuju Sejarah Sumatera Antara Indonesia dan Dunia.Jakarta: Yayasan Obor Indonesia.

Schimmel, Annemari (1975). Dimensi Mistik dalam Islam. Jakarta: Pustaka Firdaus.

Siadeka, Guslita. (2017). "Spiritualitas Masyarakat Urban (Studi terhadap Gerakan Shalat Subuh Berjamaah di Banda Aceh)," UIN Ar-Raniry, Banda Aceh.

Stogdill, Ralph,M. (1974).Handbook of Leadership. Collier Macmillian Publisher, London.

Subagyo, Joko P. (2004). Metode Penelitian: Dalam Teori dan Praktek, Jakarta: Rineka Cipta.

Sugiyono. (2002).Metode Penelitian Administrasi, Jakarta: Djambatan.

Sumarno, Edi. (2006). Mundurnya Kota Pelabuhan Tradisional di SumateraTimur Pada Periode Kolonial. Buletin Historisme.

Supriatna, yayat. (2010). "Revolusi Karakter dan Budaya Kerja Aparatur Sipil Negara Melalui Penguatan Dimensi Religiusitas, "Jurnal Ilmu Administrasi, Vol. XIV. December 2017.

Thoha, Miftah, Manajemen Kepegawaian Sipil di Indonesia, Cet. IV; Jakarta: Kencana Prenada,.

Tim Penyusun Kamus Pembinaan dan Pengembangan Bahasa, Kamus Besar Bahasa Indonesia Jakarta, Balai Pustaka.1988.

Zastrow, Charles H. (1999). The Practice Work, University of Wisconsin, An International, White Water: Thompson Publishing Company.

Zinnbauer, B., \& Pergament, K.I. (2005). Religiousness and spirituality. sIn R.F. Paloutzian, \& C.L. Park (Eds), Handbook of the psychology of religion and spirituality. New York: The Guilford Press. 